\title{
Sobre a colocação histórica dos clíticos em romeno e em português
}

\author{
Simona Ailenii*
}

Data de recepción: 26/04/2020 | Data de aceptación: 09/08/2021

\begin{abstract}
Resumo:
Neste estudo, propõe-se uma análise diacrónica comparatista dos fenómenos da próclise e da ênclise dos constituintes morfossintácticos do grupo verbal, como as formas átonas dos pronomes pessoal, reflexo e os verbos auxiliares (marcas dos tempos verbais do indicativo: futuro, perfect compus, mai-mult-ca-perfect perifrastic), em romeno, e o equivalente destes em português europeu. Dois critérios são considerados: a sua ocorrência em textos originais e traduzidos, atestando o estado arcaico das línguas, e o conteúdo dos textos, segundo a sua variação estilística (não literária e literária). O objectivo é mostrar uma possível aproximação entre os extremos linguísticos laterais românicos que apresentam, na própria diacronia, um carácter variável similar no que respeita à colocação dos elementos morfossintácticos. A finalidade é (com)provar a hipótese da tendência individual das línguas e não necessariamente e/ou exclusivamente a hipótese da influência da parte de uma(s) língua(s) com mais prestígio, em circulação, no respectivo domínio linguístico (séc. XIIIXIV para o português e séc. XVI-XVII para o romeno).
\end{abstract}

\section{Palavras-chave:}

Clíticos; romeno; português; texto original; texto traduzido; variação diafásica.

\section{Sumário:}

1. A ênclise pronominal em textos originais e traduzidos romenos. 2. A próclise pronominal em textos originais e traduzidos romenos. 3. A ênclise e a próclise pronominal em textos originais e traduzidos portugueses. 4. A anteposição e a posposição verbal em romeno e em português. Agradecimentos. Referências bibliográficas. Designações, siglas e textos. Outros textos.

* Orcid 0000-0003-1810-8485. simona.ailenii@uaic.ro. Universidade “Alexandru Ioan Cuza” de Iași/ SMELPS-IF-UP. Roménia. 


\title{
On the historical order of clitics in Romanian and Portuguese
}

\begin{abstract}
:
In this study, we propose a diachronic comparative analysis of the proclitic and enclitic morphosyntactic constituents of the verbal phrase, such as the atonic forms of personal and reflexive pronouns and the auxiliary verbs (as marks of the verbal tenses of the indicative: future, perfect compus, periphrastic mai-mult-ca-perfect), in Romanian, and their equivalents in Portuguese. Two criteria are considered: its occurrence in the original and translated texts, that prove the archaic state of the two languages, and the content of the texts, according to their stylistic variation (non literary and literary). The aim is to draw attention to a possible approximation between the Romance lateral extremes which present, in their diachrony, a similar variable character regarding the order of morphosyntactic elements. We intend to prove the hypothesis of the individual tendency of languages and not necessarily and/or exclusively the hypothesis of the influence of more prestigious language(s), in circulation, in the linguistic domain in question (XIII ${ }^{\text {th }}$-XIV ${ }^{\text {th }}$ c. for Portuguese and $X V I^{\text {th }}-X V I I^{\text {th }}$ c. for Romanian).
\end{abstract}

\section{Keywords:}

Clitics; Romanian; Portuguese; original text; translated text; diaphasic variation.

\section{Contents:}

1. Pronominal enclisis in Romanian original and translated texts. 2. Pronominal proclisis in original and translated Romanian texts. 3. Pronominal enclisis and proclisis in Portuguese original and translated texts. 4. Verbal anteposition and postposition in Romanian and Portuguese. Acknowledgments. References. Designations, acronyms and texts. Other texts. 
Neste estudo, propõe-se uma análise diacrónica comparatista dos fenómenos da próclise e da ênclise dos constituintes morfossintácticos do grupo verbal, a saber, as formas átonas dos pronomes pessoal e reflexo e os verbos auxiliares (marcas de tempos verbais compostos do indicativo: futuro, perfect compus ${ }^{1}$, pretérito maisque-perfeito perifrástico ${ }^{2}$ ). $\mathrm{Na}$ literatura da área da romanística, estes aspectos são objecto de estudo, mas com menos relevo no caso romeno quando se trata do âmbito panromânico. Contudo, o nosso propósito é chamar a atenção para uma possível aproximação entre os extremos linguísticos laterais românicos que apresentam, na própria diacronia, um carácter variável similar no que respeita à colocação dos constituintes morfossintácticos mencionados. Esta aproximação terá como objectivo (com)provar a hipótese da tendência individual das línguas e não necessariamente e/ou exclusivamente da influência da parte de uma(s) língua(s) com mais prestígio, na época, em circulação e em contacto pelo acto da tradução, no respectivo domínio linguístico. $\mathrm{Na}$ análise, realizada na perspectiva da variação textual diafásica, tomase em consideração dois critérios: a proveniência do texto (original e tradução) e, implicitamente, o registo da língua do texto (não literário e literário). Para tal, serão considerados textos que documentam, por um lado, o estado arcaico, registado no texto original e traduzido, das duas línguas românicas em estudo e, por outro, a sua variedade linguístico-estilística, registada no texto original e traduzido. No que concerne ao primeiro critério, a proveniência do texto, em romeno, os textos antigos originais e traduzidos aos quais nos referimos são datados dos séculos XVI e XVII, e em português europeu, os textos antigos originais e traduzidos aos quais nos referimos são datados dos séculos XIII e XIV ${ }^{3}$. Quanto ao segundo critério, o registo da língua do texto, temos em conta, para ilustrar o fenómeno linguístico indicado, textos de registos estilísticos equivalentes. Ou seja, em romeno e em português, será observado o respectivo fenómeno nos textos não-literários (epistolar, notarial, historiográfico, jurídico-administrativo, religioso) e nos textos literários, com um profundo conteúdo religioso, histórico ou laico, em geral.

Em romeno, os textos originais não-literários são: os epistolares (doravante designados Scrisori) e os notariais recolhidos na colecção intitulada Documenta Romaniae

1 Será utilizada a designação romena, dado que, apesar da similitude no plano da forma e até na denominação com a forma portuguesa do pretérito perfeito composto, a dissimilitude no plano semântico é significativa e impede a correspondência total entre estas formas verbais, relevando-se a individualidade das línguas em comparação. Para outros detalhes, ver adiante a discussão da n. 10.

2 Esta forma verbal perifrástica ou supra-composta é atestada e específica do estado arcaico da língua romena, enquanto na norma actual se regista apenas como característica diatópica, nos dialectos do norte do país (Frâncu, 2009: 311).

3 O estado arcaico das línguas românicas não corresponde cronologicamente, devido a vários factores relacionados com a história dos povos, história com repercussões implícitas no exercício das línguas na escrita, realizado, segundo os testemunhos conhecidos até hoje, em períodos distintos. 
Historica (doravante designados Documenta); o texto original literário, com um profundo conteúdo histórico, é Letopisețul Țării Moldovei ("A Crónica do País da Moldávia"4) de Grigore Ureche ${ }^{5}$ (doravante designado Ureche). Os textos traduzidos não-literários: o jurídico-administrativo, Pravila ritorului Lucaci -doravante designado Pravila - (“O Código do Reitor Lucaci”), o religioso, Evangheliarul slavoromân de la Sibiu (1551-1553) ("Evangelho eslavo-romeno de Sibiu”) -doravante designado Evangheliar -; os textos traduzidos literários, seguindo a classificação de Chivu (2000: 35-36), são, com conteúdos profundamente religioso, histórico, popular: Psaltirea în versuri, 1673 ("Salmos em versos") do mitropolita, poeta e tradutor Dosoftei -doravante designado Dosoftei-, Palia istorică ("A Palia histórica") -doravante designado Palia istorică-, Alexie, omul lui Dumnezeu ("Alexie, o homem de Deus") -doravante designado Alexie-, Lemnul crucii ("A árvore da cruz") -doravante designado Lemnul crucii-, Alexandria-doravante designado Alexandria.

Em português, os textos originais não-literários são: a produção notarial (doravante designada Documentos), a produção historiográfica (doravante designada Crónica), disponíveis nas bases electrónicas Corpus do Português e Corpus Informatizado do Português Medieval e o texto religioso lido no Horto do Esposo (doravante designado Horto do Esposo); o texto original literário é representado pela lírica galego-portuguesa (doravante designada Cantigas); os textos traduzidos literários são: a Estória do Santo Graal, o Livro de Merlin e o Livro de Tristam (doravante designados Estória, Livro de Merlin, e respectivamente Livro de Tristam).

Chamamos a atenção, na primeira parte da análise, para a ordem variável dos clíticos pronominais (pessoal, reflexo), como traço comum do estado arcaico das duas línguas românicas, e, na segunda parte da análise, para a ordem alternativa de um constituinte morfemático, o verbo auxiliar, clítico sintáctico específico do romeno (Dobrovie-Sorin, 1994: 49, 62; Barbu, 1999: 41-43; Pană, 2015). Um aspecto, que individualiza o romeno no domínio românico, diz respeito ao inventário mais rico do seu sistema dos clíticos, segundo mostra Dobrovie-Sorin (1994: 62):

besides pronominal clitics, this language has at its disposal adverbial clitics (other than the negative adverb, which is found in all Romance languages) and clitic conjunctions (see $a$ for infinitives and să for conjunctives, [...]); more importantly, Romanian auxiliaries qualify as verbal clitics.

4 A tradução dos títulos, dos exemplos citados dos estudos romenos e dos exemplos citados dos textos romenos analisados é nossa.

5 A crónica de Grigore Ureche (1590-1647) baseia-se em várias fontes historiográficas, cujo conteúdo foi ada/adoptado segundo critérios subjectivos; transmite-se em cópias manuscritas datadas dos séculos XVII e XVIII; contempla a história do País da Moldávia do arco cronológico 1359-1594 (Panaitescu, 1955). 
Quanto à ordem variável do verbo auxiliar, observar-se-á também o fenómeno registado no português arcaico (Costa, 2010: 65), como mostrarão os exemplos na devida secção.

Relativamente à especificidade dos constituintes pronominais do sistema linguístico romeno antigo, o autor Frâncu (2009: 51) menciona que, em textos notariais, entre as três posições que estas formas podem ocupar, a medial, a proclítica e a enclítica, as últimas duas são mais frequentes. A posição medial, continua o mesmo autor (2009: 51), prevalece, nos textos religiosos, nos sintagmas verbais com o verbo auxiliar posposto e o argumento para a respectiva prevalência é oferecido pela impossibilidade de estas estruturas se iniciarem com a forma átona pronominal ou com o auxiliar. A descrição do autor romeno, relativamente à posição secundária dos "enclíticos acessórios" da frase, leva-nos a pensar na conhecida lei de Jacob Wackernagel (Mazoureau, 1938: 11, 93; Moldoveanu, 1977-1978: 62; Wackernagel, 2020) ou na versão similar, aplicada ao domínio românico, dos autores Tobler (Nicolae \& Niculescu, 2015), Mussafia (Mussafia, 1886; Mussafia, 1898). A este respeito, o trabalho dos autores Nicolae \& Niculescu (2015: 237-238), baseado em factos linguísticos dos textos que documentam a língua romena do século XVI, é convincente no que concerne à irrelevância da exclusividade enclítica dos constituintes acessórios na sintaxe romena (nomeadamente, as formas pronominais átonas). É interessante observar os argumentos aduzidos, por vários autores, em relação à ocorrência da ênclise e/ou da próclise dos constituintes pronominais, em análise, na língua romena. Neste sentido, há dois factores fonológicos na língua romena, na visão de Frâncu (1997: 126, 328-329; 2009: 51), que se relacionam com a passagem do uso enclítico para o proclítico das formas átonas do paradigma pronominal pessoal (îmi, $\hat{\imath} t ̦ i, \hat{\imath} \boldsymbol{l}, \hat{\boldsymbol{i}} \boldsymbol{i})$ e reflexo (își). Trata-se do surgimento do $\hat{\boldsymbol{\imath}}$ - protético, surgimento datado do século XVI segundo Rizescu (1964: 752-753), nestas formas pronominais e da apócope da vogal $-\boldsymbol{u}^{6}$, que pode tornar o corpo fonético da palavra menos frágil: îmi iaste unchiu (1997: 126), "é o meu tio"; își sântu (1997: 126), "são seus"; cu pizmă huliia-l (1997: 328), "com inveja caluniava-o"; cu pizmă îl huliia (1997: 328); "com inveja o caluniava”. No estudo de Alboiu \& Hill (2012), dá-se a prioridade ao uso em próclise das respectivas formas pronominais, prioridade que aduz argumentos, deste modo, ao surgimento da prótese vocálica, havendo também ocorrências pronominais proclíticas, em textos

6 Trata-se do fenómeno geral, no domínio latino, da apócape da consoante do latim vulgar, que leva, no latim do leste do Império, à apócope da vogal -u (lat. ăvuncŭlus > ro. unchi, "tio"; lat. ventǔs > ro. vint, "vento"). Os textos romenos documentam o uso das formas somente em $\boldsymbol{-} \boldsymbol{u}$ final até a época pré-moderna. Na morfologia nominal da língua romena contemporânea, por outro lado, $\boldsymbol{-} \boldsymbol{u}$ final tem a função de sufixo flexional/vogal de ligação, intermediando a expressão enclítica do artigo definido

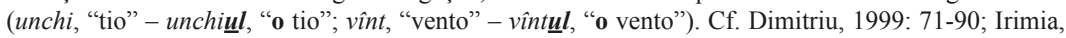
2008: 62-64. 
antigos, sem $\hat{\boldsymbol{\imath}}$ - protético: сumu $\boldsymbol{i}$-au dat împăratul slobozie (2012:10) "como lhe deu o imperador a liberdade". Da comparação das duas demonstrações, salientase a relação implícita entre a propagação da próclise do constituinte pronominal átono e a substituição das suas formas sem î- protético com as formas que têm î- protético (Frâncu, 1997: 329). A análise dos textos antigos revela ocorrências, em posição proclítica em relação ao verbo de base, tanto das formas pronominais com a característica fonética do î- protético: fratele maiceei meale îmi iaste unchiu -“o irmão da minha mãe é o meu tio" (Pravila, 169 / 227 ); como das formas pronominais sem a respectiva característica fonética: sora maiceei meale deaci mi și iaste mătuşe -“a irmã da minha mãe então é a minha tia" (Pravila, 169 / 227v); a título de exemplo para o uso em posição enclítica do pronome átono sem a vogal protética, regista-se a sintaxe iaste-mi nepot de vară -"é meu sobrinho de prima" (Pravila, $168 / 226^{v}$ ). O fenómeno genérico da ordem dos clíticos pronominais é o tema também abordado por Reinheimer Rîpeanu (2002: 199-212) e Pană Dindelegan (2003: 87-102). Trata-se das três formas de concretização da colocação clítica pronominal proporcionadas pela organização morfemática da estrutura verbal romena em que ocorre o respectivo constituinte. Com base nos exemplos dos textos estudados, observa-se: quando a estrutura verbal é sintética, o clítico pronominal pode ocupar duas posições - pré-verbal ou proclítica (mă închin, "me inclino") e pós-verbal ou enclítica (închinu-mă, "inclino-me"); quando a estrutura verbal é perifrástica, o clítico pronominal pode ocupar três posições -pré-verbal ou proclítica (m-am închinat, "inclinei-me"; $\boldsymbol{m} \breve{a}^{7}$ voi închina, "inclinar-me-ei”),

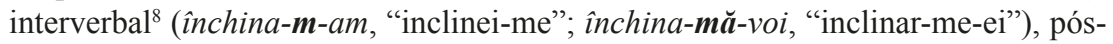
verbal ou enclítica (ai datu-mi em Dosoftei: Salmo 17, "me deste / deste-me"; cum va hi-le voia em Scrisori: 66, "como será a vontade deles").

Sobre a situação correspondente das formas átonas do pronome pessoal, em português arcaico, podemos ler na História do Galego-Português de Maia (1997: 668-672).

7 Em função do traço fonético inicial (vocálico ou consonântico) do constituinte de base seguinte, o clítico pronominal apresenta alomorfemas com distribuição distinta. Por exemplo, a forma pronominal da primeira pessoa, $\boldsymbol{m}$-/-m-, é distribuída no contexto vocálico inicial do constituinte de base seguinte do sintagma verbal: $\underline{\boldsymbol{m}}-\underline{\boldsymbol{a}} \boldsymbol{m}$ închinat/închina $\underline{-\boldsymbol{m}}-\underline{\boldsymbol{a}} \boldsymbol{m}$; enquanto a variante $\boldsymbol{m} \breve{a}$ é compatível com o contexto consonântico inicial do constituinte de base do sintagma verbal: $\underline{\boldsymbol{m a}} \underline{\boldsymbol{v}} \underline{\boldsymbol{v}} \boldsymbol{i}$ închina.

8 No domínio português, esta situação é descrita pelo termo de especialidade mesóclise, que implica a colocação do pronome átono entre os morfemas radical e desinência verbal, caso específico da morfologia sintética verbal, por exemplo, do futuro do indicativo (inclinar-me-ei); enquanto no domínio romeno, a estrutura verbal equivalente apresenta somente perífrase, constituída do verbo auxiliar e do verbo principal (închina-mă-voi), que permite a colocação do pronome átono inter-perífrase. A possibilidade proclítica é comum às duas línguas (me inclinarei, mă voi închina), mas em condições distintas, como se vai referir. Apesar de não serem objecto de estudo, assinalamos que as sequências analíticas do futuro português são também base da interposição dos clíticos (vou-te amar = vou amar-te), facto devido, provavelmene, ao estatuto de verbos semiauxiliares temporais (GRAM, 408). 
É uma obra em que, além de se registar o inventário das formas pronominais, para todas as pessoas gramaticais, se oferece, igualmente, a indicação quanto às posições que estes elementos ocupam no sintagma verbal arcaico, ocorrendo tanto em próclise, como em ênclise. A variação da ordem deste constituinte pronominal torna relevante a aproximação entre os dois domínios linguísticos românicos. Indagando ainda a literatura da área, num outro estudo de Martins (2016), em que se analisa a colocação dos clíticos pronominais, dos pontos de vista sincrónico e diacrónico, afirma-se que "nos contextos em que só a ênclise ocorre no português contemporâneo, pode observar-se variação entre ênclise e próclise no português medieval." (2016: 414). Na língua portuguesa, há certos padrões, conforme GRAM (847-867), em relação à posição proclítica dos constituintes átonos pronominais, como se explica em qualquer estudo normativo. Isto é, há elementos linguísticos com a função de "proclisadores" (Martins, 2016: 407) ou "atractores de próclise" (GRAM, 853), a saber, os quantificadores (algo, alguém, ambos, cada etc.), marcadores de foco (inclusivos: também, até, mesmo; exclusivos: apenas, só, logo etc.; aspectuais: ainda, já, quase etc.), marcadores de ênfase (bem, até, sempre, já etc.), advérbios focalizadores (deícticos locativos: aí, ali, aqui etc.; alguns advérbios em -mente), constituintes não-adverbiais focalizados, interrogativas e exclamativas e outras situações detalhadamente apresentadas nos estudos acima mencionados (GRAM, 853-864; Martins, 2016: 407-411).

O constituinte morfemático do grupo verbal, exclusiva e especificamente do domínio romeno, o verbo auxiliar, como já mencionámos, apresenta uma colocação variável semelhante ao do clítico pronominal relacionada com o verbo de base. Em romeno, há três realizações deste morfema gramatical, fulcral na estrutura morfemática do tempo verbal composto: os auxiliares a avea (< lat. hăběo, hăbère), "ter"; a fi (< at. sum, esse, fui), "ser"; e a vrea (< lat. vŏlo, velle), "querer". O primeiro morfema auxiliar é, nos casos aqui analisados, a marca do perfect compus do indicativo (am dansat, "dancei") ); o segundo é, nos casos aqui examinados, a marca do

9 A morfologia dos tempos verbais do pretérito do indicativo em romeno contemporâneo e a dos tempos verbais do pretérito do indicativo em português contemporâneo apresentam similitudes. Ou seja, tanto em romeno, como em português existe, aproximadamente, o mesmo número de tempos verbais e até nas denominações se nota alguma identidade. Chamamos a atenção para aspectos descritivos relativamente à organização morfemática das formas verbais, porque no plano semântico não há a mesma sobreposição entre os dois contextos românicos, ou seja, há menos correspondência, como se verá através da tradução dos casos. O sintetismo da forma romena dansai (perfect simplu) corresponderia ao sintetismo da forma portuguesa dancei (pretérito perfeito simples); a estrutura sintética romena dansasem (mai-mult-ca-perfect) corresponderia à estrutura sintética dançara (pretérito mais-que-perfeito simples); a construção analítica romena am dansat (perfect compus) corresponderia à construção analítica portuguesa tenho dançado (pretérito perfeito composto). Contudo, em relação ao plano léxico-semântico destas formas gramaticais, há detalhes significativos que afastam as línguas em comparação. Por exemplo, a forma romena dansai, denominada perfect 
pretérito mais-que-perfeito perifrástico (au fost cumpărat ${ }^{10}$, "tinham comprado"); e, finalmente, o terceiro é, nos casos aqui comentados, a marca do futuro do indicativo (voi dansa, "dançarei/vou dançar"11). Sobre a ordem destes constituintes no estado antigo do romeno, Frâncu (2009: 113, 310) chama a atenção para o facto de que se situam tanto em próclise, como em ênclise. É pertinente observar a particulidade da realização da posição enclítica deste elemento verbal.

\section{A ênclise pronominal em textos originais e traduzidos romenos}

1.1. Nos textos epistolares, é possível observar uma ordem variável no que respeita às formas pronominais átonas ocorrentes no sintagma verbal sintético ou perifrástico. Nos exemplos que seguem, ilustra-se a ocorrência da ênclise dos pronomes átonos.

simplu, não poderia ser equivalida pelo pretérito perfeito simples dancei, dado o semantismo temporal e/ou aspectual distinto das duas formas gramaticais. As equivalências semânticas realizam-se da forma seguinte: em romeno, dansai (perfect simplu) conhece o equivalente semântico na estrutura acabei de dançar (perifrase com o núcleo verbal no pretérito perfeito simples; em romeno, am dansat (perfect compus) conhece o equivalente semântico na forma dancei (pretérito perfeito simples); em romeno, dansasem (mai-mult-ca-perfect) conhece o equivalente semântico na forma tinha dançado (pretérito mais-que-perfeito composto). Em relação às formas compostas do pretérito mais-que-perfeito em romeno, ver n. 12.

10 Forma verbal perifrástica ou supra-composta: au fost (verbo auxiliar a fi, "ser" no perfect compus) + cumpărat (verbo principal no particípio passado). Para detalhes, ver n. 2, 12 .

11 As estruturas morfemáticas do futuro do indicativo romeno são analíticas, sendo constituídas das seguintes formas: (a) com base no verbo auxiliar a vrea e na forma do infinitivo do verbo principal, mantendo-se, assim, a perífrase etimológica latina volo + infinitivo (voi dansa / vei dansa "dançarei" / "dançarás"); (b) com base no verbo auxiliar a avea flexível e na forma do conjuntivo do verbo principal (am să dansez / ai să dansezi, "hei-de dançar" ou "vou dançar" / "hás-de dançar" ou "vais dançar"); (c) com base no mesmo verbo auxiliar a avea, mas, desta vez, inflexível e na mesma forma do conjuntivo do verbo principal (o să dansez / o să dansezi, "hei-de dançar" ou "vou dançar" / "hásde dançar" ou "vais dançar"). Estas perífrases verbais tornam-se características que individualizam o romeno, no domínio românico, pela exclusividade analítica na expressão do futuro do indicativo. Há alguns aspectos semântico-estilísticos que dizem respeito a estes sintagmas verbais: a estrutura (a) é específica da variedade literária da língua, enquanto as estruturas (b) e (c) são específicas da linguagem popular; ainda sobre a construção analítica (a), salienta-se que, no sistema romeno, se regista a variedade com o apagamento da consoante inicial (oi dansa, "dançarei”), considerada específica do uso coloquial da língua; em relação à perífrase (b), no sistema antigo romeno, encontra-se a variedade com o verbo principal no infinitivo (am a dansa, "hei-de dançar" ou "vou dançar"), infinitivo do verbo principal que tem sido substituído pelo conjuntivo, aspecto histórico tratado por Frâncu, 2000. Para a parte histórica desta descrição, ver também Fischer, 1985:108-110; Sala 1998: 116-117. Entre as formas do futuro indicadas, somente a literária é considerada na análise, cuja equivalência portuguesa considerada é a forma sintética. 
(1) Rōgu-măă să aibă ačei ōameni răi čertare mare (Scrisori, 59)

"Peço que esses homens maus sejam muito admoestados"

(2) [...] înkinu- $\underline{\text { ă }}$ Mării tale cu sănătate (Scrisori, 72)

"[...] inclino-me perante a vossa Alteza com saúde"

(3) mulțemim de čestea dumneloro vostre, dămo- $\underline{\mathbf{v a}}$ ștere dumnelor vostre (Scrisori, 66)

"Agradecemos à vossa senhoria, damos a conhecer à vossa senhoria"

(4) no știm daca să vor înprěuna, cumu va hi-le vōia (Scrisori, 66)

"não sabemos se ficarão juntos, como será a vontade deles"

Nestes trechos, mostra-se o uso da ênclise pronominal tanto em sintagma verbal sintético, Rogu-mă (1), înkinu-mă (2), dămo-vă (3), como em sintagma verbal analítico va hi-le (4). Mencionou-se acima a irrelevância da lei de Jacob Wachernagel no domínio romeno e disto temos prova, por exemplo, nos casos (1)-(3), em que os respectivos sintagmas verbais de base, situados tanto em posição inicial, Rogu-mă (1), como em posição medial, înkinu-mă (2), dămo-vă (3), do enunciado, mostram um uso generalizado da ênclise pronominal. Não é menos significativo reparar nas (dis)semelhanças das posições pronominais átonas dos dois sistemas românicos aqui comparados. O aspecto (dis)semelhante é a ordem enclítica destes constituintes. Isto é, no domínio romeno, limita-se ao uso particular no estado antigo, enquanto no domínio do português padrão actual se perpetua como norma da língua, embora em certas condições, dadas pela presença ou ausência dos elementos proclisadores, como supra se mencionou. Evidentemente que, na perspectiva de Coșeriu (1994a; 1994b), nos dois sistemas linguísticos comparados, os dois fenómenos continuam possíveis, viáveis e usados quer como marcas sinstráticas e/ou diastráticas, quer como marcas sinfásicas e/ou diafásicas. Assim sendo, ao longo desta análise, é relevante sublinhar o facto de que a ênclise e/ou a próclise pronominal átona, ocorrentes, como teremos oportunidade de ver, em todos os textos aqui considerados -textos que atestam, por um lado, estados antigos distintos da língua romena e que são, por outro lado, textos originais e traduções com um conteúdo estilístico variável (epistolar, jurídico-administrativo, religioso, beletrístico)-, se mantêm na língua actual como marca estilística, ou seja, como forma de conservadorismo e/ou de arcaísmo, nomeadamente nos textos religiosos e beletrísticos. $\mathrm{O}$ caso (4) destaca-se pela ênclise do pronome pessoal átono da $3^{\mathrm{a}}$ pessoa na perífrase do futuro do indicativo romeno. A particularidade da ênclise pronominal átona deste exemplo é a posição pós-perífrase verbal ( $v a$ hi-le). Em outras ocasiões, registadas tanto em textos originais, como em textos traduzidos, infra comentadas, será possível observar este carácter multivariável da colocação do constituinte pronominal pessoal da $3^{\mathrm{a}}$ pessoa $\mathrm{sg}$. fem., em relação às perífrases de base do futuro e do perfect compus do indicativo romeno. 
A ênclise pronominal, segundo Klimkowski (2007: 292 e sqq.), ocorre exclusivamente em textos traduzidos e é fruto do servilismo do modelo do texto original (eslavo eclesiástico). Como (de)mo(n)stram os exemplos acima expostos, e como teremos ainda oportunidade de salientar, este fenómeno é marca do uso antigo, sendo a ênclise das formas pronominais átonas uma característica do latim e dos estados arcaicos das línguas românicas, conforme também afirma Frâncu (1982: 83-84).

1.2. Os textos jurídico-administrativos são datados dos anos 1630-1632. É notável, na estrutura verbal destes testemunhos, o predomínio das formas pretéritas compostas do indicativo, ou seja, em primeiro lugar, destaca-se a forma do perfect compus (vîndutu-m-am, Documenta, 86-87), que tem, no plano do conteúdo, o equivalente português no pretérito perfeito simples ("vendi-me"); em segundo lugar, mai-mult-ca-perfect supra-compus (fostu-l-amu cumpăratu, Documenta, 69-70), que tem, no plano do conteúdo, o equivalente português pretérito maisque-perfeito composto ${ }^{12}$ ("tinha-o comprado"). O uso predominante, nestes textos, das formas pretéritas relaciona-se com o conteúdo específico que neles se revela e que é determinante nas respectivas opções das formas verbais. Ou seja, trata-se de acções passadas que foram documentadas por escrito e com testemunhos humanos. A análise dos contextos verbais perifrásticos de base revela o mesmo uso enclítico (interperifrástico) pronominal reflexo e pessoal.

(4) Însă acestŭ țiganŭ cu sălașulŭ lui fostu-l-amŭ cumpăratŭ noi (Documenta, 69) "Mas este cigano com a sua habitação tínhamo-lo comprado nós"

12 Em romeno arcaico, na sua área nórdica, o tempo verbal mais-que-perfeito do indicativo conhece cinco estruturas, das quais uma é sintética e outras quatro analíticas (três compostas e uma supra-composta). Há dois verbos auxiliares, a fi, "ser" e a avea, "ter", especializados na organização morfemática destas perífrases. Entre estas estruturas analíticas, três mostram a preferência para o auxiliar a fi: (1) era auzit, "tinha entendido"; (2) am fost mers, "tinha ido"; (3) fusese zis, "tinha dito"; e uma quarta, para o auxiliar a avea: (4) avea agonisit, "tinha lacrado". O verbo principal conjuga-se, em todas as estruturas analíticas, na forma do particípio passado. Queremos salientar dois aspectos, em relação às construções compostas do tempo verbal em causa: em primeiro lugar, as formas dos auxiliares romenos variam $-\mathrm{O}$ caso (1) apresenta o auxiliar a fi no imperfeito (era) e faz com que esta forma seja, estruturalmente, semelhante ao pretérito mais-que-perfeito composto português; o caso (2), o mesmo auxiliar a fi, no pretérito perfeito composto (am fost) e faz com que esta forma seja considerada supra-composta; o caso (3), o mesmo auxiliar a fi, no mais-que-perfeito sintético (fusese) e, finalmente, o caso (4) apresenta o outro auxiliar, a avea, no imperfeito (avea) e faz com que esta forma seja semelhante, estruturalmente, ao pretérito mais-que-perfeito composto português - ; em segundo lugar, o romeno actual perdeu, na norma padrão, as formas compostas, mantendo apenas a forma sintética, enquanto o português actual regista duas formas deste tempo verbal, a sintética e a composta. Os exemplos em romeno são extraídos do exaustivo estudo do autor Frâncu, 2009: 113-115. Como supra se mencionou, na n. 2, a forma considerada supra-composta, o número (2) na ordem deste breve inventário, é marca dialectal nórdica em romeno actual. 
(5) Ce văzîndu eu atîta căutare, sculatu- $\underline{\underline{m}-a m}$ de-am venit înnaintea domnnu nostru Io Leon voevoda (Documenta, 107)

"E vendo eu tanta demanda, levantei-me e vim diante do nosso fidalgo voivoda Io Leon"

(6) am luat bani ce-s mai sus-scriși, tîmplatu-ș-au mărturie de au fost de față (Documenta, 46)

"recebi o dinheiro cima escrito, aconteceu que havia pessoas presentes"

Além do aspecto principal da nossa análise (a documentação da ordem dos clíticos pronominais e dos verbos auxiliares do sintagma verbal de base), parece-nos igualmente relevante chamar a atenção para o estado antigo da língua romena que pode ser caracterizado por mais possibilidades de expressão, em relação às formas do mesmo tempo verbal, do que a organização do estado actual. Este facto parece natural, aliás, dado que o uso arcaico de qualquer língua se encontra ainda em fase de construção, de constituição que conduz à estabilidade, à estandardização conferida, em grande medida, pelos trabalhos normativos realizados em várias épocas. A análise destes factos permite-nos, contudo, observar que há um grau superior de semelhança entre o estado antigo da língua romena e o estado antigo e actual da língua portuguesa. Os casos destacados mostram a ênclise (interperífrase) pronominal átona -fostu-l-amŭ cumpăratŭ (4), sculatu-m-am (5), tîmplatu-sau (6) - específica do estado arcaico do romeno e ocorrida em sintagmas verbais perifrásticos. Pelas traduções oferecidas - "tínhamo-lo comprado" (4), "levanteime" (5), "aconteceu-se" (6)- e típicas da norma actual portuguesa, é possível notar a semelhança entre a ordem das formas pronominais átonas nos dois idiomas comparados. Esta disposição pronominal já não é norma em romeno literário actual e a forma (supra-)composta do pretérito mais-que-perfeito também não, (4), enquanto em português, as duas situações (a ênclise e a próclise) são parte da sua norma actual. Evidentemente, estas formas verbais permitem observar que há, contudo, uma distinção entre a ordem do verbo auxiliar em romeno e a ordem do verbo auxiliar em português, mas teremos oportunidade de assinalar adiante ocorrências do verbo auxiliar proclítico em romeno, semelhante ao uso em português actual (am fost cumpărat o vie -Documenta, 160-16 -, "tinha comprado uma vinha").

1.3. No domínio romeno, há textos antigos com conteúdo histórico, como crónicas ou cronógrafos, sobre os quais Chivu (2000: 80) nos dá a conhecer o facto de que estas obras atestam meios específicos da arte literária e os tornam, deste modo, testemunhos da linguagem literária, não científica. Assim sendo, representando uma estilística literária peculiar, é possível observar o uso das formas pronominais em ênclise nestas páginas históricas redigidas no século XVII. 
(7) Află-s̆ă această țară să fie fostu lăcuit și alții într-însa mai nainte de noi (Ureche, 61)

"Sabe-se que este país foi habitado também por outros antes de nós"

(8) Iară ce va fi trecut înapoi nu să află însemnat de streini, cunoaști-să că cum nu să află de scriitorii noștri însemnat viiața domnilor şi lucrurile lor [...] (Ureche, 67)

"E o que se passou dantes não foi registado pelos estrangeiros; saiba-se que, assim como não se encontra escrita pelos nossos cronistas a vida dos reis e os actos deles [...]"

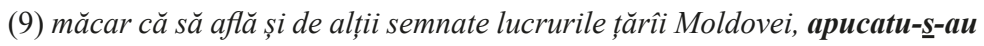
și dumnealui de au scris începătura și adaosul (Ureche, 57)

"ainda que tivessem sido escritos por outros os actos do país da Moldávia, ele põe-se também a escrever o começo e o continuação"

(9.1) Chiematu o a a unii și Flachia, ce scriu letopisețele latinești (Ureche, 59)

"Chamaram-na alguns também de Flachia, como dizem as crónicas latinas"

(9.2) Că crescîndu vrajba între creștini, au luat Misia, Licaoniia, Frighia,

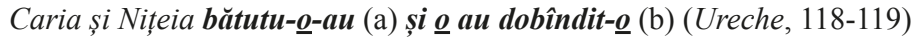

"E aumentando o ódio entre os cristãos, tomaram Misia, Licaoniia, Frighia, Caria e a Nițeia derrotaram-na e conquistaram-na"

(9.3) Și cățeaoa cu care au gonit fiara aceia au crăpat, pre carea o au chiemat-o Molda (Ureche, 60)

"E a cadela com a qual caçaram aquela besta morreu, e chamava-se Molda"

Os exemplos seleccionados das páginas do Letopisețul Țării Moldovei permitem-nos entender, mais uma vez, que o uso da ênclise não é condicionado, em romeno arcaico, pela posição inicial na oração do contexto gramatical em que ocorre o elemento átono. Na situação (7), regista-se a utilização da ênclise no contexto gramatical inicial (Află-š̆), mas nas situações (8) e (9), notam-se outras ênclises pronominais átonas ocorridas num contexto gramatical no interior da frase. Chama-se a atenção para a realização variável da ênclise: interverbal, nas perífrases de base apucatu-s-au (9), Chiematu o au (9.1) e bătutu-o-au (9.2 a); e anteverbal/anteperífrase (próclise) e pós-verbal/pós-perífrase (ênclise), nos exemplos perifrásticos $\boldsymbol{o}$ au dobîndit-o (9.2 b) e $\boldsymbol{o}$ au chiemat-o (9.3). Entende-se, pelo emprego redundante do pronome átono, demonstrado através dos últimos dois exemplos, $(9.2$ b e 9.3$)$, o carácter flexível e enfático da língua. Estes tipos enclíticos pronominais átonos poderão ainda ser observados, ao longo da análise, com base em textos traduzidos. Passemos a ver a concretização do mesmo fenómeno da ênclise pronominal em textos oriundos do acto de tradução.

Os casos que se apresentam em seguida são extraídos de textos romenos traduzidos ou do eslavo eclesiástico ou de outras línguas. Ao factor da língua fonte, ao qual 
remete a autora Reinheimer Rîpeanu (2002: 202), conferimos, nesta análise, uma ponderação menor, dado o facto de que os fenómenos da ênclise e da próclise têm uma configuração e uma frequência similares às dos textos originais e até dão lugar a desenvolvimentos linguísticos criativos atestados em obras originais e traduzidas, como teremos ocasião de encontrar nos textos literários em análise.

1.4. Os casos (10) e (11), seleccionados do texto jurídico-administrativo, documentam a ocorrência da ênclise pronominal átona tanto no contexto verbal situado no início da oração (Cade-se), como no interior da oração (iaste-mi). $\mathrm{O}$ texto traduzido testemunha também esta colocação pronominal como específica do uso antigo da língua.

(10) Cade-se a ști [...], că fiecăruia ce-s însoțiți în lume [...] cuscrie se cheamă (Pravila, 168)

"Convém saber $[\ldots]$ que todos os que são acompanhados na vida $[\ldots]$ chamam-se parentes"

(11) Iarră feciorul a veareei premare-mi iaste-mi nepot (Pravila, 168)

"E o filho da minha prima mais velha é meu sobrinho"

1.5. Conforme os casos oriundos da tradução romena do texto bíblico Evangheliar, nota-se um uso similar enclítico do pronome átono.

(12) Obărși-ș Duminica (Evangheliar, f. 3²)

"Acabou-se o Domingo"

(13) Iaca un gubav închină-sia Lui greind [...] (Evangheliar, f. 17v)

"Eis um leproso que se inclina perante Ele dizendo [...]"

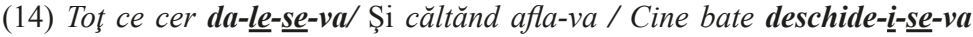
(Evangheliar, f. 14v)

"A todos os que pedem dar-se-lhes-á/ E procurando descobrirão/ A quem bate abrir-se-lhe-á"

(15) De plodul lor cunoşte-î-vreț (Evangheliar, f. 15v)

"Pelos seus frutos conhecê-los-eis"

Em primeiro lugar, assinala-se que o sintagma verbal de base ${ }^{13}$ do constituinte pronominal átono se situa quer no início da oração, quer no interior da oração. Em segundo lugar, o pronome átono conhece uma colocação variável em função

$13 \mathrm{O}$ conceito da estrutura gramatical-suporte do constituinte pronominal átono foi teorizado por Pană Dindelegan, 2003. 
da morfologia do sintagma verbal de base. Referimo-nos, então, à colocação pósverbal (enclítica) em sintagma verbal sintético -Obărşi-se (12), închină-sia (13)-, e à colocação interverbal em sintagma verbal perifrástico - da-le-se-va, deschide$\boldsymbol{i}$-se-va (14), cunoşte-i-vreţ (15). Dois aspectos queremos salientar partindo destes exemplos. Por um lado, a colocação pós ou interverbal é, como já mencionámos, específica do estado antigo da língua romena em contextos verbais ilustrados ao longo da análise ${ }^{14}$ (conjugação no presente, no perfect compus, no futuro do indicativo). Esta ordem morfemática é mantida, com preponderância, na norma actual dos textos religiosos como marca estilística do conservadorismo deste registo linguístico. Um primeiro exemplo neste sentido é oferecido no texto bíblico do Evangelho de Mateus, 28:18 -Datu-mi-s-a toată puterea în cer și pe pământ (Biblia sau Sfânta Scriptură, 2008), "É-me dado todo o poder, no céu e na terra" (Bíblia Sagrada, 2001)-; e um segundo exemplo, no livro de oração Acatistul Sfântului Ierarh Nicolae (s.d.: 11), "Litania do Santo Hierarca Nicolae" - Arătatu-te-ai în vis impăratului, "Revelaste-te ao imperador no sonho". Por outro lado, partindo dos sintagmas do exemplo (14) -da-le-se-va, deschide-i-se-va-, em que as perífrases verbais, conjugadas no futuro do indicativo, são a base dos dois clíticos, o pessoal -le-/-i-, "-lhes-/-lhe-", e o reflexo -se-, "-se-", repare-se a relevância da aproximação entre a colocação interverbal dos clíticos nas formas que atestam o estado antigo da língua romena e a similar colocação interverbal ou mesóclise dos clíticos nas formas que se mantêm no estado actual da língua portuguesa. Em romeno, o carácter variável da colocação pronominal tem, na norma actual, motivações estilísticas, enquanto em português, morfossintácticas, como supra se mencionou, em contexto gramatical ausente de elementos proclisadores.

1.6. A leitura dos textos beletrísticos antigos, representando traduções, permite observar que há alguma preferência pela ênclise pronominal átona no discurso directo, talvez como marca estilística do diálogo. Poderia esta tendência ser um sinal de que este recurso linguístico já tinha, na época, a função de marca de expressividade? É apenas uma hipótese que não descartamos e talvez o texto de Dosoftei, que veremos adiante, a sustente. Foram extraídas situações de três textos que são testemunhos da variação popular do estilo literário (Alexandria, Lemnul crucii, Palia istorică).

(16) 'Și cuget, maica [t] a oare vede-te-va, au nu te va mai [vede]? '(Alexandria, 206)

“"E penso, a tua mãe ver-te-á, ou não te vai ver mais?”

14 A situação dos modos verbais do imperativo e gerúndio não é comentada, representando contextos gramaticais que implicam, no estado antigo e actual da língua, a colocação enclítica do pronome átono. 
(17) Por-Împărat sculă-să și cu oștile lui și merge la [A]lexandru (Alexandria, 167)

"Por-Imperador levantou o seu exército contra Alexandre"

(18) Iar într-o noapte văzu Alixandru în vis pre Irimiia-Proroc şi-i zise: 'Fătul mieu Alixandre, umplură-s $\underline{a} 40$ de ani [...]' (Alexandria, 235-236)

"E numa noite o Irimiia-Profeta viu Alexandre em sonhos e disse-lhe: 'Meu filho Alexandre, cumprem-se 40 anos [...]"'

(19) Iară tâlhariul ce crezu,/răstignitu-l-au pre lemnul ce era sămnat (Lemnul crucii, 198)

"E o ladrão que teve fé, foi crucificado no pedaço de madeira que estava assinado"

(20) Eva zise: 'Zisu-ne-au Dumnezeu să nu ne atingem de lemnul vieții' (Palia istorică, 103)

"Eva disse: 'Disse-nos Deus para não tocar na árvore da vida""

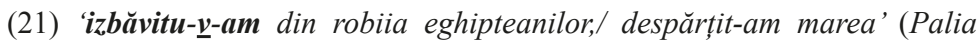
istorică, 186)

“"libertei-vos da escravidão dos egípcios,/ separei o mar"”

Os casos (17) e (18) de Alexandria mostram a já habitual ênclise pronominal átona

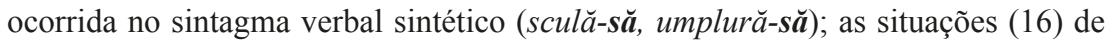
Alexandria (vede-te-va), (19) de Lemnul crucii (răstignitu-l-au) e (20) e (21) de Palia istorică (Zisu-ne-au, izbăvitu-v-am), como outras anteriormente apresentadas, permitem observar que o predomínio da ênclise pronominal interverbal ou pósverbal se deve à posposição de um outro constituinte da perífrase verbal, isto é, o verbo auxiliar, morfema das perífrases do perfect compus do indicativo (-au< a avea "ter", em 19 e 20) e do futuro do indicativo (-va $<$ a vrea "querer", em 16 e 21). A ênclise do verbo auxiliar faz, igualmente, objecto de estudo numa secção seguinte da análise.

Conforme mencionado acima, há um outro texto em que se desenvolve o estilo beletrístico na sua variação culta da espécie lírica literária, Psaltirea în versuri, 1673. É uma obra lírica do metropolita poeta Dosoftei, em cujo substrato se encontra uma tradução canónica do livro dos Salmos de David, realizada pelo mesmo autor. A versão lírica é o suporte da nossa análise e testemunha, como veremos, usos peculiares da inversão pronominal átona. Este facto leva-nos a pensar no valor estilístico, que o autor dá a este recurso linguístico, muitas vezes, ocasionado pelos factos prosódicos implícitos do acto criativo da expressividade lírica. Os exemplos evidenciam a variação da colocação pronominal nas seguintes equações: em primeiro lugar, destaca-se a variação exclusivamente pós-verbal; em segundo lugar, distingue-se a variação exclusivamente interverbal; e, em terceiro lugar, sempre relacionado com o fenómeno da inversão (isto é, da ênclise), individualiza-se a 
redundância pronominal, em que o autor lança a mão do uso simultâneo do mesmo clítico anteverbal e pós-verbal.

(22) Şi le vei da, Doamne, plată Pre fără legea lor faptă, Şi dup-á lor viclenie Vei pierde-i (Dosoftei, Salmo 93)

"E dar-lhes-ás, Senhor, a paga para a má acção por eles feita, E segundo a sua malícia derrotá-los-ás"

(23) Că tu, Doamne svinte, [...] Cu arma ce-ai datu- $\underline{\text { mi }}$ de-i prăvălesc iute (Dosoftei, Salmo 17)

"E tu, Senhor santo, $[\ldots]$ Com a arma que me deste para os deitar por terra velozmente"

(24) Datu-mi-ai vârtute şi mi-ai lărgit paşii (Dosoftei, Salmo 17)

"Deste-me força e aumentaste-me o passo"

(25) Iubi-te-voi, Doamne, că tu-m eşti putere (Dosoftei, Salmo 17)

"Amar-te-ei, Senhor, porque tu és a minha força"

(26) Ce eu, iarăş, am zâs şi voi zâce: 'Oare hi- $\underline{\boldsymbol{m}}$-va cândva vro ferice [...]?' (Dosoftei, Salmo 72)

"E eu, de novo, disse e direi: 'terei um dia alguma felicidade [...]?'”

Os casos (22) e (23) ilustram a exclusividade do uso pós-verbal do pronome átono, o primeiro, ocorrido na perífrase do futuro do indicativo (Vei pierde-i), e o segundo, ocorrido na perífrase do perfect compus (ai datu-mi); além da diversidade do contexto gramatical de base em que ocorre, a homogeneidade enclítica do pronome pode representar uma opção estilística baseada na procura pela rima feminina (em 22: viclenie [...] pierde-i [...] să știe). Os casos (24) e (26) mostram, desta vez, a exclusividade do emprego interverbal do mesmo clítico. No caso (24), datu-mi-ai, observam-se dois aspectos: a conjugação do mesmo verbo que em (23), ai datu-mi, e o mesmo tempo verbal (perfect compus). A distinção é a colocação pronominal pós-verbal, em 23 e interverbal, em 24. No caso derradeiro, a colocação interverbal permite obter a musicalidade entre o final da primeira perífrase verbal (Datu-mi-ai) e o início da perífrase sequinte verbal (mi-ai lărgit).

Além do uso da ênclise pronominal, concretizado em várias situações verbais, no verso de Dosoftei, há razões para assinalar um fenómeno linguístico-estilístico particular. Trata-se da redundância do pronome pessoal átono, realizada em anteposição (próclise) e posposição (ênclise), relacionada com a perífrase de base. As razões são prosódicas, como também nota Chivu (2000: 85).

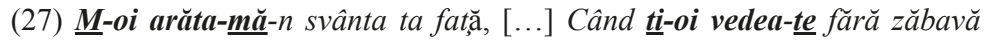
(Dosoftei, Salmo 16)

"Mostrar-me-ei perante a tua face santa, $[. .$.$] Logo que te vir"$ 


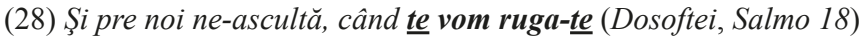

"E ouve-nos, quando te rogamos"

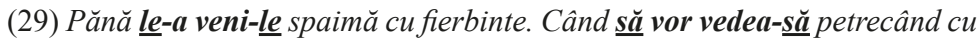
pace (Dosoftei, Salmo 52)

"Até lhes virão o medo grande do inferno. Quando se verem vivendo em paz" (30) Că tu l-ai măritu-l pre-mpăratul s-aibă Milă şi izbândă [...] (Dosoftei, Salmo 17)

"Porque tu louvaste o imperador, para ele ter piedade e triunfo [...]"

(31) Tie t-am greşitu-ț, Doamne svinte, De-am făcut răutăt denainte (Dosoftei, Salmo 50)

"Errei perante Ti, Senhor santo, pela minha muita maldade"

As perífrases de base do clítico são conjugadas no futuro em (27)-(29) e no perfect compus em (30)-(31). Casos similares da expressão redundante pronominal átona tivemos, igualmente, oportunidade de encontrar em textos originais, como o do cronista Grigore Ureche $(9.2,9.3)$, facto que nos leva a formular a hipótese de estarmos perante o emprego de meios linguísticos com valor de marcas estilísticas.

\section{A próclise pronominal em textos originais e traduzidos romenos}

2.1. Começamos a análise do fenómeno linguístico da próclise pronominal com base nos textos originais. Nas cartas romenas, a perífrase do perfect compus destaca-se, no estado antigo da língua, como base verbal que conhece a próclise da forma pronominal pessoal átona da $3^{a}$ pessoa sg. fem., situação não mantida na norma actual. Notase um outro aspecto relevante que provavelmente motiva esta próclise pronominal: a anteposição de um outro constituinte fundamental da perífrase verbal, o verbo auxiliar (a) avea. Com se referiu acima, em relação à ênclise do mesmo pronome $\mathrm{e}$ dos outros, a respectiva colocação enclítica pronominal encontra-se interrelacionada com a ênclise do constituinte verbo auxiliar, facto igualmente notável no caso da próclise, ou seja, a pronominal pode ser proporcionada pela verbal.

(32) Dečii Ursul o au dat vorničilor ěpa [...]; şi ěpa încă o am trimis la dumniěvostră (Scrisori, 74-75)

"Então Ursul deu-a aos governadores [a égua] [...]; e também mandámos a égua para o senhor"

(33) iară Petre Șutra o au cumpărat la zi de trîg den trîg de Nemțu dila noi (Scrisori, 49)

"e Petre Șutra comprou-a a nós no dia da feira da cidade de Nemţu" 
Nos casos (32) e (33), conjugam-se, na forma perfect compus, três verbos distintos (o au dat; o am trimis; o au cumpărat), base do clítico anteverbal da $3^{\text {a }}$ pessoa sg. fem.. A colocação proclítica deste pronome, registada nos textos antigos, pode ter sido influenciada também pela colocação proclítica das outras formas pronominais átonas pessoais e/ou reflexas: $\boldsymbol{l}$ - ( $3^{\mathrm{a}}$ pessoa $\mathrm{sg}$. $\mathrm{m}$.) em $\boldsymbol{l}$-av cumpărat fečorul lui Macsim (Scrisori, 49), "comprou-o o filho de Macsim"; nё- (1 $1^{\text {a }}$ pessoa pl.) em пё-и dzis domnu nostru (Scrisori, 60), "disse-nos o nosso senhor"; se- ( $3^{\text {a }}$ pessoa sg.) em če se-u dat în măra noastră (Scrisori, 60), "o que se foi dada nas nossas mãos".

2.2. O texto jurídico-administrativo, testemunho de produção original, oferece igualmente exemplos múltiplos da colocação anteverbal do clítico analisado -(34) e (35)- em consonância com outras formas do paradigma pronominal -(36) e (37). A norma actual não mantém, como já se mencionou, a próclise deste elemento na perífrase verbal do perfect compus. A próclise é relacionada, conforme Frâncu (2009: 174-175; 278), com a ênfase que se confere ao objecto directo da estrutura profunda, objecto expresso através desta forma pronominal.

(34) Și o am vîndut de bunăvoia mea și cu știrea tuturor megiiaşilor (Documenta, 47)

"E vendi-a de minha boa vontade e com o conhecimento de todos os vizinhos"

(35) Și o am dat de a mea bunăvoe, pentru că au fost moșie a mea dreaptă (Documenta, 178)

"E dei-a de minha boa vontade, porque foi a minha terra de direito"

(36) Deci mi-am ales partea mea toată, de o- $\mathbf{m}$ vîndut derept dumnealor (Documenta, 90)

"Então escolhi para mim toda a minha parte, e vendi-a directamente aos senhores"

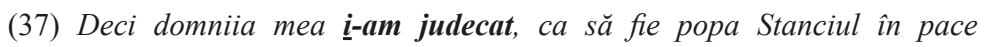
(Documenta, 341-342)

"Então, minha senhoria, julguei-os, para que o padre Stanciu ficasse em paz"

2.3. A crónica de Grigore Ureche representa um terceiro momento dos textos originais seleccionados, em que se registam, igualmente, casos da próclise pronominal átona.

(38) și după multă goană ce o au gonit-o prin munți cu dulăi, o au scos la şesul apei Moldovei (Ureche, 60) 
"e depois da longa corrida em que a caçaram pelas montanhas com cães, fizeram com que ela chegasse à beira do rio da Moldávia"

(39) de multe ori i-au și biruit, mai apoi de o au și supus supt gingul lor (Ureche, 64)

"e muitas vezes os venceram, depois de a terem submetido ao seu jugo"

Pela tradução oferecida é fácil notar a distância que se produz entre os estados das línguas românicas, tomando em consideração o facto de que o português actual mantém a próclise de todas as formas pronominais na presença de um elemento proclisador (que, depois de).

2.4. Entre os textos traduzidos, da Palia istorică, o exemplo 40 ilustra o uso da próclise pronominal reflexa (s̆a) e pessoal da $3^{\text {a }}$ pessoa sg. fem. (o).

(40) Atuncea păstoriul $\underline{\text { să }}$ intoarse cătră Iuda și dzise: 'Nu o am aflat pre

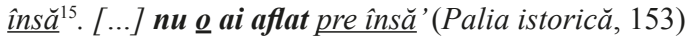

"Então o pastor virou-se para Judas e disse: 'Não a descobri. [...] não a descobriste"”

\section{A ênclise e a próclise pronominal em textos originais e traduzidos portugueses}

Não temos o objectivo de descrever a situação dos fenómenos da ênclise e da próclise presentes no estado arcaico da língua portuguesa, mas de a exemplificar como elemento de (dis)cordância, segundo mostrarão os casos, com o estado arcaico da língua romena.

3.1. Nos textos notariais, representando a produção linguística original na presente análise, evidenciam-se casos da ênclise pronominal, mantida na norma actual (41) ou não (42). No texto historiográfico, produção linguística original, em relação à próclise - (43) - revela-se, de novo, a mesma variabilidade notória do estado arcaico da língua: a próclise ocorre tanto na ausência do elemento proclisador (lhe disse, 43 a), como na presença deste (que lhe pareçia, 43 b).

15 A expressão por pronomes pessoais do objecto directo realiza-se de forma redundante nas duas situações sublinhadas, a saber, as duas ocorrências do pronome $o$ (< lat. ullam) e as outras duas ocorrências do contexto pronominal pre însă $(<$ lat. ipsa), precedido pela preposição específica do acusativo pre $(<$ lat. per $)$. 
(41) Emprazaram $\underline{\text { lhe }}$ asi as ditas casas cõ seu cortinhal ao dito Afomso (Documentos)

(42) e cõ outras confrontaços a quall bjnha lhe asy enprazaram como dito he so (Documentos)

(43) \& ho comde lhe disse (a) que lhe pareçia (b) que aquelles homẽes moviam come gemte que queria pellejar (Crónica)

3.2. No texto religioso escolhido como outro testemunho da produção linguística original, Horto do Esposo, também se observa o uso variável da ênclise (44, 45, 46 b, 47) e da próclise (46 a) dos constituintes pronominais átonos.

(44) E entom foy-sse Luciano ao bispo de Jerusalem e recontou-lhe todo esto e o bispo chamou outros bispos consigo e forõ-se a huũ luguar que Gamaliel mostrara a Luciano (Horto do Esposo, 26)

(45) e emtom lhe pregũtava algũas cousas daquelles livros (Horto do Esposo, 52)

(46) o coyro se ẽverruga (a) e seca-sse (b) e o baffo cheyra mal e o peyto offega (Horto do Esposo, 130)

(47) E aquelle que he boto do entendimẽto nõ deve leyxar de leer ameude, por tal que afazendo-sse a leer e amãdo as Sanctas Scripturas (Horto do Esposo, 55)

3.3. O texto literário original destaca-se por um outro tipo de variabilidade proporcionada pela particularidade da língua portuguesa no que respeita à colocação pronominal surgida no sintagma verbal-suporte: a forma do futuro do indicativo, que pode implicar o fenómeno da mesóclise.

(48) e dar-pos-ei em ajuda muito coteife vilão (Cantigas, Afonso X)

(49) e direi-yos em que lho entendi (Cantigas, Martim Soares)

O uso da mesóclise em (48) e o uso da ênclise em (49) põem em relevo os recursos linguísticos escolhidos, provavelmente, com base em razões prosódicas na lírica portuguesa. O caso (48) mostra uma equivalência parcial de colocação específica apenas ao estado arcaico do romeno, ou seja, a colocação interverbal na perífrasesuporte conjugada no perfect compus e no futuro do indicativo, como tivemos oportunidade supra de observar (batutu-o-au, 9.2; cunoște-i-vreț, 15; vede-te-va, 16). Estes exemplos vêm mostrar que o carácter livre da colocação pronominal pessoal e/ou reflexa é, igualmente, específico do estado arcaico da língua portuguesa atestado nos textos originais. 
3.4. No que respeitam aos textos traduzidos portugueses em que a ênclise e a próclise se manifestam, situações extraídas dos três textos arturianos vêm reforçar o fenómeno da variabilidade específica do estado arcaico da língua. Chamar-se-á a atenção para os casos que mostram a possibilidade de aproximar tipos semelhantes de variação na colocação pronominal.

(50) Entõ espydyo se del rrey e de ssua conpanha e rrogou-lhes (Estória, 403 / f. $\left.1^{\mathrm{r}} \mathrm{II}\right)$

(51) entõ sse partyrom deles. E eles tornarõ sse coydando e chorãdo (Estória, 403 / f. $1^{\text {rIII })}$

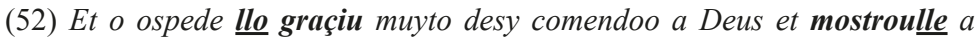
carreyra pera Seraloys assy como a amostrara ao da ssaya mal tallada (Livro de Tristam, 75 / 11. 34-36)

(53) Et a reyna sse confortou muyto que logo foy guarida (Livro de Tristam, 73 / 11. 4-6)

(54) Rey Euelac disse ela ssenpre oune ssabor [...] eu te liurarey e leuarey te a a mays ffremosa casa (Estória, 406 / f. $2^{\mathrm{v}} \mathrm{II}$ )

(55) Se te non quitas dessa conpanha eu matarey ty ou eela (Livro de Merlin, $151 / 11.9-10)$

Os casos (50) e (51) mostram o mesmo tipo de variabilidade que se sublinhou através dos exemplos (44) e (45), oriundos do texto original no registo religioso, na presença adverbial entõ. Quanto às selecções (52) e (53), é notável, em primeiro lugar, a utilização variável da próclise, sem e com elemento proclisador, e, em segundo lugar, a utilização da ênclise comum à norma actual também. Com base nos contextos gramaticais de (54), é possível, uma vez mais, assinalar a variação na colocação pronominal, te liurarey e leuarey te, em que não há o concurso do elemento proclisador para o primeiro sintagma verbal, por exemplo. Em (54) e (55) evidencia-se um aspecto que pode permitir a aproximação entre a colocação pronominal átona encontrada nos estados arcaicos das duas línguas românicas: os sintagmas verbais-suporte do futuro, ao contrário da norma actual que supõe a mesóclise, conhecem a colocação pós-verbal (ênclise) do pronome átono, leuarey te, matarey ty. Uma situação semelhante foi assinalada no caso das selecções extraídas da lírica portuguesa (direi-vos, 49). Em romeno, casos da colocação pós-verbal (ênclise) encontram-se, igualmente, tanto em texto original, em sintagma verbal-suporte conjugado no futuro (cum va hi-le voia, 4), como em texto traduzido, em sintagma verbal-suporte conjugado no perfect compus (Cu arma ce-ai datu-mi, 23), como característica do estado arcaico da língua. 


\section{A anteposição e a posposição verbal em romeno e em português}

Referimo-nos aos auxiliares (a) avea, da estrutura morfemática do perfect compus, e (a) vrea, da do futuro. Os textos analisados, originais e traduzidos, estilisticamente variados, apresentam ocorrências deste constituinte tanto em anteposição, como em posposição da perífrase verbal de base.

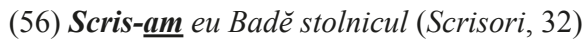

"Escrevi eu, Bade, o mordomo"

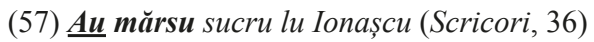

"Foi-se o sogro de Ionașcu"

(58) peste patru dzile veni-va la scaunul dumisale (Scrisori, 56)

"em quatro dias virá ao seu trono"

(59) de nu va hi așĕ, să nu mai avem credință la dumniavoastră (Scrisori, 57) "se não for assim, que não tenham mais fé em nós"

(60) Ce văzîndu eu atîta căutare, sculatu-m- $\underline{\mathbf{a m}}$ de-am venit înnaintea domnnu nostru Io Leon voevoda (Documenta, 106-107)

"E vendo eu tanta demanda, levantei-me e vim diante do nosso fidalgo voivoda Io Leon"

(61) mi-am văndut toată partea mea de ocină (Documenta, 47)

"vendi toda a minha parte da terra"

(62) apucatu-s-âu şi dumnealui de au scris începătura şi adaosul (Ureche, 57)

"ele põe-se também a escrever o começo e o continuação"

(63) și de va avea strîmbătate, afla- $\underline{\boldsymbol{v a}}$ județu (Ureche, 113)

"e se estiver errado, o juiz descobri-lo-á"

Com base nos casos extraídos dos textos originais, Scrisori, Documenta, Ureche, evidencia-se a variação da colocação do auxiliar nas duas perífrases verbais em análise. Os exemplos (56)-(57), registados nas cartas de 1592-1638, põem em relevo a ênclise (Scris-am) e a próclise ( $\boldsymbol{A} \boldsymbol{u}$ mărsu) do morfema verbal da perífrase do perfect compus; enquanto os casos (58)-(59) põem em relevo a mesma variação ocorrida na perífrase do futuro (veni-va, va hi). As selecções dos documentos notariais, (60)-(61), e da crónica de Grigore Ureche, (62)-(63), dão a possibilidade de observar o mesmo fenómeno da variação quanto à colocação do morfema na perífrase verbal do perfect compus (sculatu-m-am, apucatu-s-au vs. am văndut, au scris) e do futuro (va avea vs. afla-va).

(64) Feri-va Dumnedzău pre toți pre ceia ce-l iubăsc (Pravila, 172)

"Deus protegerá a todos os que o amam" 
(65) iară nu se va afla așea [...] (Pravila, 175)

"e se não se descobrir assim [...]"

(66) De vret iarta ominilor greșelele lor, iarta- $\underline{\mathbf{v a}}$ şi voo Tată vostr (Evangheliar, ff. $11^{\mathrm{r}}-11^{\mathrm{v}}$ )

"Se vós perdoardes às pessoas os seus erros, perdoar-vos-á o vosso Pai do céu" (67) audzit- $\underline{\text { at }}$ că dzis este batrănilor (Evangheliar, f. $6^{\mathrm{r}}$ )

"ouvistes o que aos velhos foi dito"

(68) şi va da carte că s- $\underline{\text { au }}$ împarţit (Evangheliar, f. $7^{\mathrm{v}}$ )

"e dará carta porque se separaram"

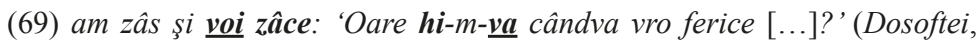
Salmo 72)

"disse e direi: 'terei um dia alguma felicidade [...]?"”

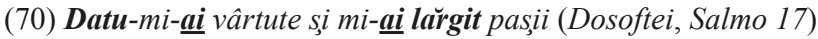

"Deste-me força e aumentaste-me o passo"

Os exemplos seleccionados dos textos traduzidos mostram, em consonância com os oriundos dos originais, a mesma oposição na disposição do morfema auxiliar nas perífrases em análise. Em cada texto, observa-se a alternância da ênclise com a próclise, no que concerne à ordem dos constituintes tanto na perífrase do futuro, como na do perfect compus do indicativo. Os casos da Pravila, (64)-(65), evidenciam, quanto à perífrase do futuro, o uso alternativo da ênclise do morfema auxiliar (Feri-va) e da próclise do mesmo morfema auxiliar (se va afla). O caso (66) do Evangheliar mostra a mesma alternância, em primeiro lugar, no que respeita à perífrase do futuro (vreț iarta - iarta-va); e os casos (67)-(68), a permutação do morfema auxiliar na estrutura perifrástica do perfect compus (audzit-aț-s-au imparţit). E, por último, nos casos de Dosoftei, (69)-(70), sublinha-se a variação na colocação da marca morfemática dos dois tempos verbais: o futuro em próclise do verbo auxiliar em voi zâce e em ênclise do verbo auxiliar em hi-m-va; o perfect compus em ênclise do verbo auxiliar em datu-mi-ai e em próclise do verbo auxiliar em ai largit. A norma actual é caracterizada pela ordem proclítica da marca morfemática destes tempos verbais, embora há registos da língua que valorizam o fenómeno da ênclise como marcas estilísticas.

Como já se mencionou acima, no português arcaico, também há registos de posposição $(71,72)$ e anteposição $(73,74)$ do auxiliar aver, conforme os exemplos seguintes:

(71) pregumtado do sexto artigo disse o que dito avia no quinto artigo (Documentos)

(72) El Con Symon muitas vezes jurado avia que o trobador matasse (Cantigas) 
(73) e que Ulcano lhe avia outorgado que vencesse todas as batalhas em que entrasse (Crónica)

(74) e a mercee que Deus avia feita a el rei dom Afomso (Crónica)

Em conclusão, em primeiro lugar, o estado arcaico das duas línguas românicas pode ser caracterizado por um grau maior de liberdade no que respeita à colocação dos clíticos, liberdade que deve ter a ver com o facto de as línguas ainda estarem em curso de se normatizarem, sendo a variação uma característica intrínseca do processo de unificação do sistema. Em segundo lugar, é possível notar características do estado antigo da língua romena que permitem aproximá-lo do estado actual da língua portuguesa. De facto, o uso arcaico do romeno valoriza possibilidades de expressão semelhantes ao português actual (próclise, por exemplo, apesar de ser condicionada pelos elementos proclisadores). Contudo, nos registos religioso e/ ou literário da língua romena actual e até nas expressões populares, estes recursos arcaicos tornam-se marca estilística. Os fenómenos da próclise ou ênclise não parecem intrinsecamente relacionado com o modelo do eslavo eclesiástico no que respeita à sua presença em romeno, sendo registados em produções textuais originais e traduzidas. Ora, as causas dos fenómenos podem ser tanto internas, como externas. Os casos analisados permitem formular a hipótese de poder ter havido tendências das línguas românicas com base nas quais se manifesta o carácter variável da colocação dos clíticos.

\section{Agradecimentos}

Agradecemos à Marta Afonso e à Rafaela Silva as preciosas explicações em relação a tantos aspectos da história da língua portuguesa, da sua norma actual e da tradução dos exemplos. Os erros que ficaram são da responsabilidade da autora.

\section{Referências bibliográficas}

\section{Designações, siglas e textos}

Alexandria $=$ Zgraon, Florentina (ed.) (2006). Alexandria. Vol. XI. Cele mai vechi cărți populare în literatura română. București: Fundația Națională pentru Știință şi Artă; Grigoriu, Brînduşa (ed.) (2020). ALIXĂNDRIA: le premier roman roumain d'Alexandre le Grand. Éd. bilingue de la rédaction du Codex Neagoeanus, trad., introd. et notes par Grigoriu Brînduşa selon l'éd. de Florentina Zgraon. Cluj-Napoca: Presa Universitară Clujeană. 
Alexie $=$ Stanciu-Istrate, Maria (ed.) (2006). Alexie, omul lui Dumnezeu. Vol. V. Cele mai vechi cărți populare în literatura română, 13-106. București: Fundația Națională pentru Știință și Artă.

Cantigas = Cantigas Medievais Galego-Portuguesas. Disponível em http://cantigas. fcsh.unl.pt/listacantigas.asp (Consultado em 20.12.2020); "Cantigas de Santa Maria”. Corpus do Português. Disponível em https://www.corpusdoportugues.org/ hist-gen/ (Consultado em 01.04.2021).

Crónica $=$ "Crónica do Conde D. Pedro de Meneses - ZPM - Livro 1 - Titulo 45, Séc. XV". Corpus Informatizado do Português Medieval. Disponível em https:// cipm.fcsh.unl.pt//corpus/texto.jsp?t=t\&id=24376 (Consultado em 04.01.2021); “Crónica de Espanha de 1344”. Corpus do Português. Disponível em https://www. corpusdoportugues.org/hist-gen/ (Consultado em 01.04.2021).

Documenta = Mihoc, Damaschin (ed.) (1969). Documenta Romaniae Historica, B. Tara Românească (1630-1632). Vol. XXIII. București: Editura Academiei Române.

Documentos $=$ "Documentos do Mosteiro de Santa Cruz de Coimbra", "Documentos do Mosteiro de Santa Cruz de Coimbra", "Chartularium Universitatis Portugalensis vol. 1". Corpus do Português. Disponível em https://www.corpusdoportugues.org/ hist-gen/ (Consultado em 01.04.2021).

Dosoftei $=$ Dosoftei (1974). Psaltirea în versuri, 1673. Ed. de N. A. Ursu. Disponível em http://nicugane.ro/articole/biblioteca/DOSOFTEI\%20-\%20Psaltirea\%20in\%20 versuri.pdf (consultado em 29.03.2021).

Estória = Ailenii, Simona (2019). Os primeiros testemunhos da tradução galegoportuguesa do romance arturiano, 375-419. Porto: Estratégias Criativas.

Evangheliar = Petrovici, Emil (ed.) (1971). Evangheliarul slavo-român de la Sibiu (1551-1553). București: Editura Academiei Române.

Horto do Esposo = Modena, Martina (ed.) (2016). Horto do Esposo. Edizione critica elettronica. Settore scientifico disciplinare di afferenza: L-FIL-LET/10. Tesi di Dottorato, matricola 825511. Venezia: Università Ca'Foscari Venezia. Disponível em http://dspace.unive.it/bitstream/handle/10579/8277/825511-1166803.pdf?sequence=2 (Consultado em 07.02.2021).

Lemnul crucii = Timotin, Emanuela (ed.) (2006). Lemnul crucii. Vol. V. Cele mai vechi cărți populare în literatura română, 107-199. București: Fundația Națională pentru Ştiință și Artă.

Livro de Merlin = Lorenzo Gradín, Pilar, Souto Cabo, José António, Arbor Aldea, Mariña, Guttiérez García, Santiago, López Martínez-Morás, Santiago, Pérez Barcala, Gerardo, Díaz Martínez, Eva María, \& Poncia, Leonardo (eds.) (2001a). Livro de Tristan e Livro de Merlin. Estudio, edición, notas e glosario, 149-157. Santiago de Compostela: Centro de Ramón Piñero para a Investigacións en Humanidades / Xunta de Galicia. 
Livro de Tristam = Lorenzo Gradín, Pilar, Souto Cabo, José António, Arbor Aldea, Mariña, Guttiérez García, Santiago, López Martínez-Morás, Santiago, Pérez Barcala, Gerardo, Díaz Martínez, Eva María, \& Poncia, Leonardo (eds.) (2001b). Livro de Tristan e Livro de Merlin. Estudio, edición, notas e glosario, 71-84. Santiago de Compostela: Centro de Ramón Piñero para a Investigacións en Humanidades / Xunta de Galicia.

Palia istorică = Moraru, Alexandra, \& Moraru, Mihai (eds.) (2006). Palia istorică. Vol. IV. Cele mai vechi cărți populare în literatura română. București: Fundația Națională pentru Știință și Artă.

Pravila = Rizescu, Ioan (ed.) (1971). Pravila ritorului Lucaci. București: Editura Academiei Române.

Scrisori $=$ Rosetti, Alexandru (ed.) (1944). Scrisori românești din Arhivele Bistriței (1592-1638). București: Casa Şcoalelor.

Ureche $=$ Ureche, Grigore (1955). Letopisețul Țării Moldovei. Ed. de P. P. Panaitescu. București: Editura de Stat pentru Literatură și Artă.

\section{Outros textos}

Acatistul Sfântului Ierarh Nicolae (s.d.). Bacău: Editura Bunavestire.

Bíblia Sagrada (2001). Trad. de João Ferreira de Almeida. Lisboa: Sociedade Bíblica de Portugal.

Biblia sau Sfânta Scriptură (2008). Tipărită cu binecuvântarea Preafericitului Părinte Daniel, Patriarhul Bisericii Ortodoxe Române, cu aprobarea Sfântului Sinod. București: Editura Institutului Biblic și de Misiune Ortodoxă.

\section{Estudos e dicionários}

Alboiu, Gabriela, \& Hill, Virginia (2012). "Early Mordern Romanian and Wackernagel's Law”, SKY Journal of Linguistics, 25, 7-28. Disponível em http://www.linguistics.fi/ julkaisut/SKY2012/SKYJoL_2012.pdf (Consultado em 22.03.2021).

Barbu, Ana Maria (1999). “Complexul verbal”, Studii și Cercetări Lingvistice, 50, 1, 39-84.

Buescu, Victor (coord.) (1977). Dicionário de Romeno-Português. Porto: Porto Editora.

Chivu, Gheorghe (2000). Limba română de la primele texte pînă la sfirșitul secolului al XVIII-lea. Variantele stilistice. București: Editura Unvers Enciclopedic.

Costa, Maria João (2010). "Os verbos aver e teer no português arcaico - breve sinopse”, Filología e Linguística Portuguesa, 12 (1), 59-68. Disponível em https://www. revistas.usp.br/flp/issue/view/4919 (Consultado em 22.03.2021). 
Coșeriu, Eugen (1994a). “Arhitectura și structura limbii”, Prelegeri şi conferinţe, 49-64. Iași: Institutul de Filologie Română "A. Philippide".

Coşeriu, Eugen (1994b). “Competenţa lingvistică”, Prelegeri şi conferinţe, 27-47. Iaşi: Institutul de Filologie Română "A. Philippide".

Dimitriu, Corneliu (1999). Tratat de gramatică a limbii române. Vol. I. Morfologia. Iaşi: Institutul European.

Dobrovie-Sorin, Carmen (1994). The Syntax of Romanian. Ed. de Jan Koster \& Henk van Riemsdijk. Berlin / New York: Mouton de Gruyter.

Fischer, Iancu (1985). Latina dunăreană. București: Editura Ştiințifică și Enciclopedică.

Frâncu, Constantin (1982). "Formele verbale și pronominale cu î-protetic în limba română", Dacoromania. Jahrbuch für östliche Latinität, V, 1979-1980, Herausgegeben von Paul Miron, 80-93. Freiburg / München: Verlag Karl Alber.

Frâncu, Constantin (2000). Conjunctivul românesc și raporturile lui cu alte moduri. Iași: Casa Editorială Demiurg.

Frâncu, Constantin (2009). Gramatica limbii române vechi (1521-1780). Iași: Casa Editorială Demiurg.

Frâncu, Constantin (1997). "Morfologia". Em Gheție, Ion (coord.), Istoria limbii române literare. Epoca veche (1532-1780), 113-146, 319-347. București: Editura Academiei Române.

GRAM = Mateus, Maria Helena Mira, Brito, Ana Maria, Duarte, Inês, Faria, Isabel Hub, Frota, Sónia, Matos, Gabriela, Oliveira, Fátima, Vigário, Marina, \& Villalva, Alina (2003) [1983]. Gramática da Língua Portuguesa. Lisboa: Editorial Caminho.

Klimkowski, Tomasz (2007). "Influența slavonă asupra ordinii cuvintelor în texte românești vechi”, Annales Universitatis Apulensis. Series Philologica, 8 (1), 291297. Disponível em https://www.academia.edu/7538617/Influența_slavonă_asupra_ ordinii_cuvintelor_în_texte_românești_vechi (Consultado em 22.03.2021).

Irimia, Dumitru (2008). Gramatica limbii române. Ed. a III-a. Iași: Editura Polirom.

Maia, Clarinda de Azevedo (1997) [1986]. História do Galego-Português: estado linguístico da Galiza e do Noroeste de Portugal desde o século XIII ao século XVI (com referência à situação do galego moderno). Lisboa: Fundação Calouse Gulbenkian.

Martins, Ana Maria (1994). Clíticos na História do Português. Dissertação de Doutoramento. Lisboa: Universidade de Lisboa.

Martins, Ana Maria (2016). "A colocação dos pronomes clíticos em sincronia e diacronia”. Em Martins, Ana Maria, \& Carrilho, Ernestina (eds.), Manual de linguística portuguesa MRL 16, 401-430. Berlin / Boston: Walter de Gruyter. 
Mazoureau, Jean (1938). L'ordre des mots dans la phrase latine. Vol. II. Le Verbe. Paris: Société d'Édition "Les Belles Lettres".

Moldoveanu, Dragoș (1977-1978). "Formațiile premorfologice din limba română veche", Anuar de Lingvistică și Istorie literară, 26, 45-69.

Mussafia, Adolfo (1886). "Una particolarità sintattica della lingua italiana dei primi secoli”. Em Ascoli, G. I., Avolio, C., Biadene, L., Cornu, J., Crescini, V., D’Ancona, A., D’Ovidio, F., Flechia, G., Fumi, F. G., Gandino, G. B., Gaspary, A., Gaster, M., Gröber, G., Leite de Vasconcellos, J., Merlo, P., Meyer, G., Meyer, P., Michaelis de Vasconcelos, C., Miklosich, Franz., Milá, Manuel, Miola, A., Monaci, E., Morosi, G., Mussafia, A., Neumann, F., Novati, F., Obédénare, M., Paoli, C., Paris, G., Pieri, S., Rajna, P., Renier, R., Salvioni, C., Stengel, E., Suchier. H., Tobler, A., Villari, P., Wiese, B., \& Zingarelli, N. (eds.), Miscellanea di filologia e linguistica in memoria di Napoleone Caix e Ugo Angelo Canello, 255-261. Florence: Le Monnier. Disponível em https://archive.org/details/miscellaneadifil00caixuoft (Consultado em 22.03.2021).

Mussafia, Adolfo (1898). "Enclisi o proclisi del pronome personale atono quale oggeto", Romania, 27, 145-146. Disponível em https:/www.persee.fr/docAsPDF/ roma_0035-8029_1898_num_27_105_5532.pdf(Consultado em 22.03.2021).

Nicolae, Alexandru, \& Niculescu, Dana (2015). "Pronominal Clitics in Old Romanian: The Tobler-Mussafia Law”, Revue Roumaine de Linguistique, 60 (2-3), 223-242. Disponível em https://dare.uva.nl/search?identifier=bded6074-4ddb-4aad-b452c1384a9b9d4f (Consultado em 22.03.2021).

Nicolae, Alexandru, \& Niculescu, Dana (2016). "Pronominal clitics: clitic ordering, clitis clusters". Em Pană Dindelegan, Gabriela (ed.), The Syntax of Old Romanian, 52-89. Oxford: Oxford University Press.

Panaitescu, Petre P. (1955). "Introducere”. Em Ureche, Grigore, Letopisețul Țării Moldovei, 5-54. Ed. de P. P. Panaitescu. București: Editura de Stat pentru Literatură şi Artă.

Pană, Cristina (2015). "Despre encliza auxiliarului și a cliticelor pronominale", Studii și cercetări lingvistice, 66, 2, 201-211.

Pană Dindelegan, Gabriela (2003). Elemente de gramatică. Dificultăți, controverse, noi interpretări, 87-102. București: Editura Humanitas Educational.

Reinheimer Rîpeanu, Sanda (2002). "Locul pronumelor neaccentuate din limba română veche în perspectivă romanică". Em Celmare, Izabela (ed.), Actele Colocviului Catedrei de Limba Română. Perspective actuale în studiul limbii române, 22-23 noiembrie 2001, 199-212. București: Editura Universității din București.

Rizescu, Ioan (1964). "Contribuții la istoria pronumelui din limba română”, Studii și cercetări lingvistice, 15, 6, 749-753. 
Rizescu, Ioan (1971). “Introducere”. Em Rizescu, Ioan (ed.), Pravila ritorului Lucaci, 5-33. București: Editura Academiei Române.

Sala, Marius (1998). De la latină la română. București: Univers Enciclopedic.

Wackernagel, Jacob (2020). On a law of Indo-European word order: Über ein Gesetz der indogermanischen Wortstellung. Trad. George Walkden, Christina Sevdali, Morgan Macleod. Berlin: Language Science Press. 
